\title{
Vaginal Fibroepithelial Polyp
}

National Cancer Institute

\section{Source}

National Cancer Institute. Vaginal Fibroepithelial Polyp. NCI Thesaurus. Code C4948.

A superficial polypoid lesion that arises from the vagina. It is characterized by the presence of a fibroblastic stroma which is often myxoid, covered by squamous epithelial cells. 